\title{
Impacts of tidal land reclamation in Bohai Bay, China: ongoing losses of critical Yellow Sea waterbird staging and wintering sites
}

\author{
HONG-YAN YANG, BING CHEN, MARK BARTER, THEUNIS PIERSMA, \\ CHUN-FA ZHOU, FENG-SHAN LI and ZHENG-WANG ZHANG
}

\begin{abstract}
Summary
The coast of Bohai Bay, north-western Yellow Sea, is critical for waterbirds migrating along the East Asia-Australasian Flyway. Between 1994 and 2010 , a total of $450 \mathrm{~km}^{2}$ of offshore area, including $218 \mathrm{~km}^{2}$ of intertidal flats (one third of the original tidal area in the bay), has been reclaimed along the bay for two industrial projects. This has caused the northward migrants to become concentrated in an ever smaller remaining area, our core study site. The spring peak numbers of two Red Knot subspecies in the East Asia-Australasian Flyway, Calidris canutus piersmai and C. c. rogersi, in this so far little affected area increased from $13 \%$ in 2007 to $62 \%$ in 2010 of the global populations; the spring peak numbers of Curlew Sandpiper C. ferruginea increased from $3 \%$ in 2007 to $23 \%$ in 2010 of the flyway population. The decline in the extent of intertidal mudflats also affected Relict Gulls Larus relictus, listed by IUCN as 'Vulnerable'; during normal winters $56 \%$ of the global population moved from the wintering habitats that were removed in Tianjin to the relatively intact areas around Tangshan. Densities of wintering Eurasian Curlew Numenius arquata, and spring-staging Broad-billed Sandpiper Limicola falcinellus and Sanderling Calidris alba have also increased in the remaining areas. With the proposed continuation of land reclamation in Bohai Bay, we predict waterbird densities in the remaining areas to increase to a point of collapse. To evaluate the future of these fragile, shared international resources, it is vital to promote an immediate conservation action plan for the remaining coastal wetlands in this region, and continued population monitoring to determine the effects of this action.
\end{abstract}

\section{Introduction}

Coastal areas provide important habitats for many waterbird species, especially shorebirds, wildfowl, gulls and terns (van de Kam et al. 2004, 2008, Wetlands International 2006, Bamford et al. 2008). Despite their importance as providers of marine food resources and livelihoods for fishing communities, intertidal areas for centuries have been converted into land for agricultural and residential use, port construction and industrial estates (Dalby 1957, Glue 1971, Davidson et al. 1991, Suchaneck 1994, BirdLife International 2004). Whereas reclamation activities have now ceased in north-west Europe (Piersma 2009), the conversion of intertidal flats into fish- or salt ponds, agricultural, recreational, or industrial land has accelerated in eastern Asia, especially in the Yellow Sea region, in order to accommodate the pressure of increasing human populations and economic growth (Barter 2002, Moores 2006, van de Kam et al. 2008, SOAPRC 2009, Wan et al. 2009). The populations of migrating waterbirds that depend on coastal wetlands have declined in parallel with the losses of intertidal areas, in extreme cases leading to threatened or nearly extinct populations (Syroechkovskiy 2004, Crosby and Chan 2006, Wetlands International 2006, Moores et al. 2008, van de Kam et al. 2008, Amano et al. 2010, Zöckler et al. 2010). In view 
of the rapid decrease of intertidal habitats, the safeguarding of the remaining intertidal flats from further losses and degradations must become a global priority.

Here we present the case of Bohai Bay in the north-west Yellow Sea, China, strategically located in the middle of the East Asian-Australasian Flyway (hereafter EAAF). The coast of Bohai Bay is crucial to waterbirds, especially shorebirds and gulls that make stopovers there during northward and southward migration, or winter there, including Relict Gull Larus relictus, listed as 'Vulnerable' by IUCN (2010) and BirdLife International (2010a), Saunders's Gull L. saundersi, Eurasian Curlew Numenius arquata, Red Knot Calidris canutus, Curlew Sandpiper C. ferruginea and Marsh Sandpiper Tringa stagnatilis (Li et al. 1996, Barter 2002, Battley et al. 2005, Minton et al. 2006, Yang and Zhang 2006, Liu et al. 2007, Yang et al. 2008). The majority of Red Knot during northward migration, and the largest wintering populations of Eurasian Curlew and Relict Gull, were counted in Bohai Bay along the EAAF (Barter et al. 2001, 2003, Liu et al. 2006, Cao et al. 2009). Concerns about the accelerating tidal flat reclamation along the Bohai Bay coast, and the potential effects on waterbirds dependent on the bay, have been voiced earlier (Barter et al. 2003, Liu et al. 2006, Yang et al. 2008). No evidence on the impacts of the land reclamation in recent decade has so far been provided.

Bohai Bay sits next to a densely human-populated and rapidly developing region. Two industrial developments have been under construction on the western and northern coasts of Bohai Bay since 1994 (Table I): Tianjin Binhai New Area, located in the municipality of Tianjin, western Bohai Bay, and Caofeidian New Area, in the city of Tangshan, Hebei Province, northern Bohai Bay, started in 1994 and 2002, respectively (Fig. I). In the past decade, the developments have turned large areas of sea into industrial land and the rate of land reclamation has accelerated (this study). In future, the planned development will lead to a continuing reduction of both land and shallow sea habitats (Table I).

Loss of waterbird habitats can lead to a decline in waterbird numbers (e.g. Moores et al. 2008, Kraan et al. 2009, Catry et al. in press), or to the movement of birds to nearby suitable habitats (Burton et al. 2006); the latter can lead to increased densities on other sites and consequent increase in mortality of the displaced birds, thus leading to an overall loss of birds (Goss-Custard 1980). The reclamation of the two major industrial developments has changed, and will further change, waterbird habitats along the Bohai Bay coast. The aim of this study was to determine if waterbirds have declined already, or have become concentrated in the remaining suitable areas. We conducted surveys of migratory and wintering waterbirds along the coasts of Tianjin and Tangshan during 2006-2010, and were fortunate to have concentrated most survey efforts in an area relatively little impacted so far. We interpret these counts in the light of the historical extent of land reclamation, reconstructed on the basis of satellite photographs.

\section{Methods}

\section{Study area and study sites}

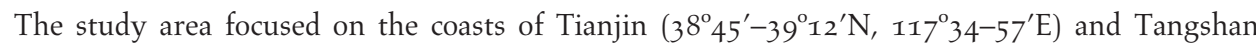
$\left(39^{\circ} \mathrm{O}-10^{\prime} \mathrm{N}, 118^{\circ} \mathrm{O} 7-21^{\prime} \mathrm{E}\right)$. The area has a typical temperate climate with cold, dry winters and

Table 1 . Details of the industrial reclamation projects in Bohai Bay. ${ }^{a}$

\begin{tabular}{|c|c|c|c|c|c|c|}
\hline Project & $\begin{array}{l}\text { Reclamation } \\
\text { period }\end{array}$ & Location & $\begin{array}{l}\text { Total } \\
\text { planned } \\
\text { area }{ }^{b}\left(\mathrm{~km}^{2}\right)\end{array}$ & $\begin{array}{l}\text { Planned intertidal } \\
\text { area reclamation } \\
\left(\mathrm{km}^{2}\right)^{\mathrm{c}}\end{array}$ & $\begin{array}{l}\text { Total planned } \\
\text { offshore area } \\
\text { reclamation }\left(\mathrm{km}^{2}\right)\end{array}$ & Main industries \\
\hline $\begin{array}{l}\text { Tianjin } \\
\text { Binhai } \\
\text { New Area }\end{array}$ & $1994-2020$ & $\begin{array}{l}\text { NW } \\
\text { Bohai Bay }\end{array}$ & 2,270 & 205 & 266 & $\begin{array}{l}\text { ports, logistics, } \\
\text { heavy equipment } \\
\text { manufacturing, } \\
\text { petrochemical }\end{array}$ \\
\hline $\begin{array}{l}\text { Caofeidian } \\
\text { New Area }\end{array}$ & $2002-2020$ & $\begin{array}{l}\mathrm{N} \\
\text { Bohai Bay }\end{array}$ & 1,943 & 142 & 130 & $\begin{array}{l}\text { ports, steel, } \\
\text { chemical, energy }\end{array}$ \\
\hline
\end{tabular}

${ }^{a}$ Data sources: SOAPRC (2009) ${ }^{b}$ Includes total land and offshore areas ${ }^{c}$ This study. 


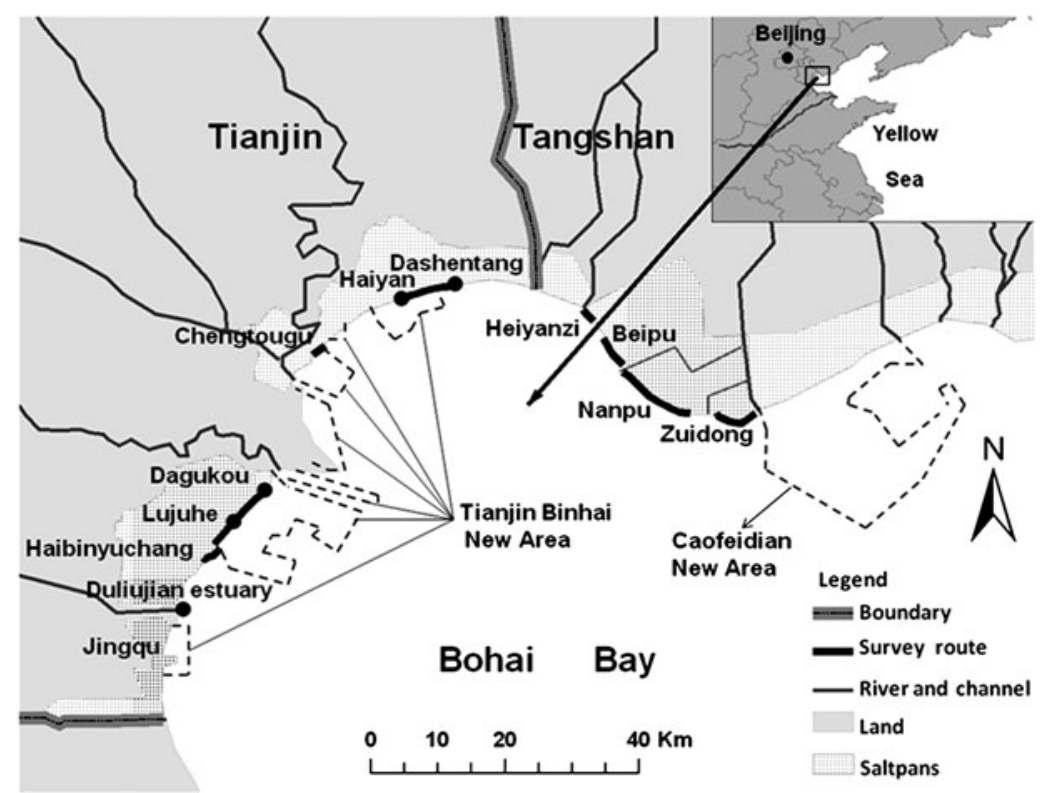

Figure 1. Location of study sites and reclaimed areas of the Tianjin Binhai and Caofeidian New Area industrial reclamation projects in Bohai Bay by 2010.

hot, humid summers. The average temperature in January is $-4^{\circ} \mathrm{C}$ and in July $26^{\circ} \mathrm{C}$ (HPDLR 2007). The intertidal area remains frozen from December for three months. The main habitats are tidal mudflats, saltpans and shrimp ponds; a sea wall separates the saltpans and shrimp ponds from the mudflats. Tides have an average range of $2.5 \mathrm{~m}$ (HPDLR 2007). The intertidal flats outside the dykes are $1-3 \mathrm{~km}$ wide at low tide (see Fig. 2) and completely submerged from about 2 hrs before time of high tide. There are salt works, wharfs, oil fields and industrial areas along the coast. Local people collect shellfish and catch fish on the mudflats from spring to autumn.

We worked at seven study sites in Tianjin: Duliujian estuary, Haibinyuchang, Lujuhe, Dagukou, Chengtougu, Haiyan and Dashentang, and four in Tangshan: Heiyanzi, Beipu, Nanpu and Zuidong (Fig. 1). The sites in Tangshan were situated between Tianjin Binhai New Area and Caofeidian New Area, but closer to the latter. However, during the study period, most study sites in Tianjin were lost gradually to land reclamation by the Tianjin Binhai New Area. The order in which the mudflats were enclosed by sea walls was: from east of Haiyan to Dashentang in October 2007, from Lujuhe to Dagukou in December 2007, from east of Haibinyuchang to Lujuhe and Chengtougu in September 2008. In Tangshan, the core study sites Beipu, Nanpu and Zuidong were only a little affected by land reclamation until late 2009, with partial land loss in Zuidong in 2010.

\section{Remote sensing data collection and processing}

To document the extent of loss of sea areas, especially of the intertidal zone, we acquired a set of Landsat MSS/TM/ETM+ images which covered a period of 36 years: 1974, 1984, 1993, 2000, 2002-2010. Land cover in the study area was classified into land, intertidal area and water, using visual interpretation and digitalization with technical support from ArcMap 9.3 (ESRI Inc. 2008). We estimated the total area of tidal flats at low tide in spring along the Tianjin and Tangshan coasts in each year, measured the tidal flats at each study site and the total offshore area, 


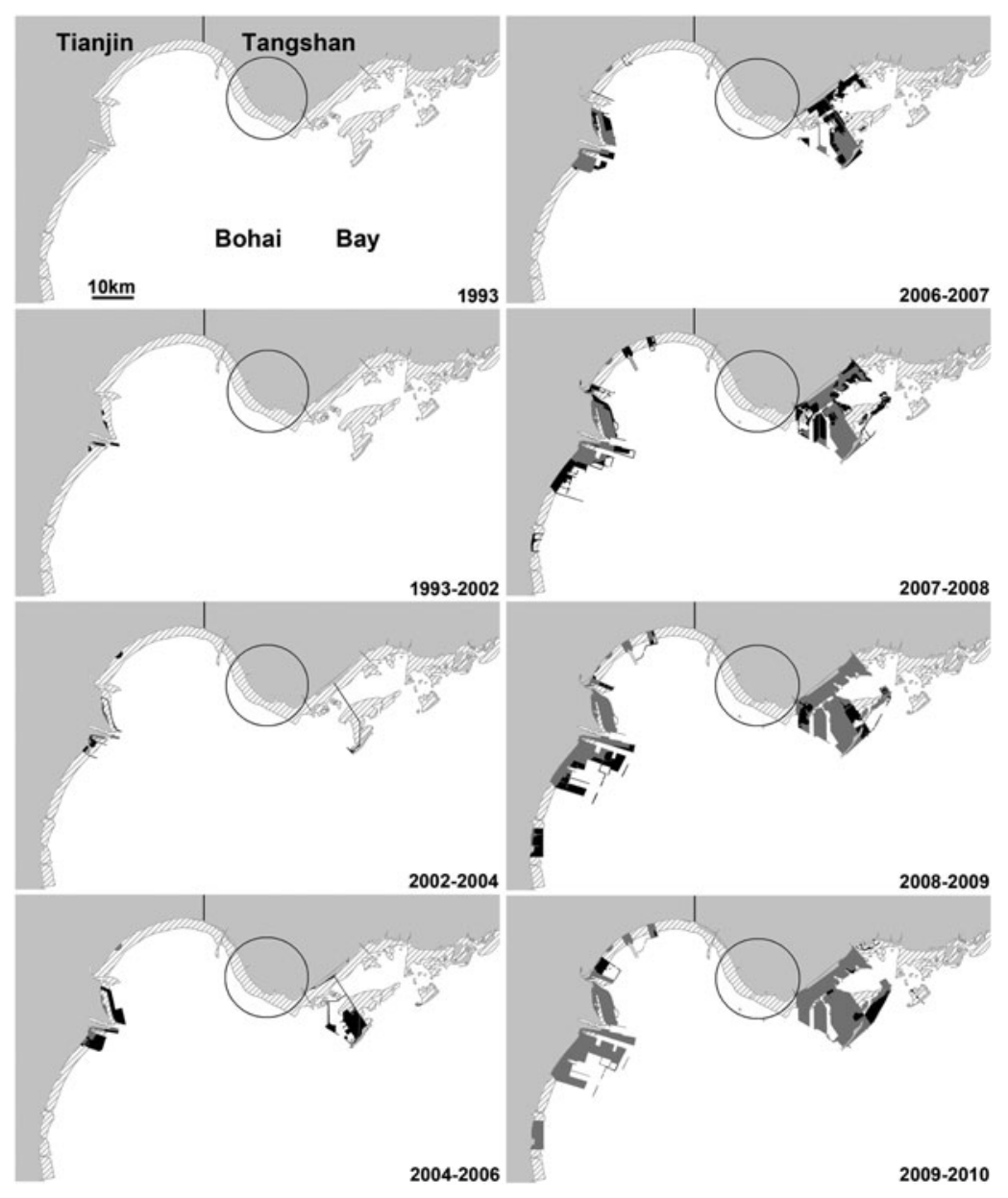

Figure 2. Changes in reclaimed offshore areas in the Tianjin Binhai and Caofeidian New Areas over years. The lined areas are intertidal flats, the area in the circle is the core study area in Tangshan (Beipu, Nanpu and Zuidong), the dark grey areas present the cumulative extent of previously reclaimed areas and the black areas show the new reclaimed areas between years, including new land, sea walls and mudflats or shallow water within closed sea walls. (The data set is provided by International Scientific Data Service Platform, Computer Network Information Center, Chinese Academy of Sciences. (http://datamirror.csdb.cn))

including tidal flats and shallow water, to be reclaimed according to project plans, and calculated the changes in land-use within industrial developments between years using ArcMap 9.3.

\section{Survey methods}

Surveys were conducted along the seawall at each study site. Survey lengths were: Duliujian estuary$1.5 \mathrm{~km}$, Haibinyuchang to Lujuhe-3 km, Lujuhe to Dagukou-6.5 km, Chengtougu-2.5 km, Haiyan to Dashentang-6 km, Heiyanzi-2 km, Beipu-4 km, Nanpu-1o km, and Zuidong-6 km.

From September 2006 to December 2008, we carried out surveys during three periods each year: one survey in September, three (2007) or six (2008) surveys in May, and monthly surveys from December to February. In 2009, surveys were conducted monthly in Tangshan except in 
May, when eight surveys were carried out. In Tangshan in 2010, one survey was conducted in January, one in February and seven surveys during May. Waterbirds on the intertidal mudflats were counted using telescopes (25-60x) and/or binoculars (10x40) during the outgoing tide. We recorded air temperatures during survey periods, as temperature can affect the distribution of wintering waterbirds (Liu et al. 2006). Combinations of sites (e.g. Haibinyuchang to Dagukou, Haibinyuchang to Lujuhe, Haiyan to Dashentang) were each usually surveyed within one day, with additional sites requiring extra counting days. Study site surveys were adjusted when necessary to account for habitat loss, but also occasionally due to bad weather or access problems caused by bad road conditions.

\section{Internationally important species}

Internationally important species are defined as those which were present in numbers $\geq 1 \%$ of their flyway populations at least once during the study period according to the Convention on Wetlands (Ramsar, Iran, 1971); shorebird flyway populations follow Bamford et al. (2008) except for Red Knot and Eurasian Curlew flyway population sizes where we used the update by Rogers et al. (2010) and Cao et al. (2009) respectively. For other waterbird species we followed Wetlands International (2006), IUCN (2010) and BirdLife International (2011).

\section{Data collection and analysis}

In order to compare annual numbers between regions and annual changes in abundance within the regions, we organised the data as follows:

(I) Surveys were carried out during May, the peak period of northward migration in the study area, from 2007 to 2010. Mean waterbird densities were calculated to show population trends of waterbirds during northward migration in different areas.

(2) Monthly surveys were conducted in every winter month from 2006/2007 to 2009/2010. Trends in wintering waterbird populations were determined by comparing the means of waterbird densities counted in December, January and February between years.

(3) To assess changes in shorebird populations in the study area before and after tidal land reclamation, we used the data from Zuidong. This was the only site within the core study area in Tangshan that had a series of comparable monthly surveys conducted since 2004, when land reclamation activities had not yet started.

(4) To verify whether this increase in waterbirds at the core study sites is indeed mainly due to habitat loss elsewhere in Bohai Bay, we used all information on known numbers of Red Knot and Curlew Sandpiper, the two most common migrant shorebirds, in combination with the known land reclamation. Assuming the staging populations in northern Bohai Bay to have remained stable, we predicted the yearly peak numbers based on the sum of the peak numbers counted in the core study area during the previous year plus the known number of birds that occurred in the reclaimed intertidal flats elsewhere in Tianjin and Tangshan along western and northern Bohai Bay in that year (Barter et al. 2001, 2003). The observed peak numbers of Red Knot and Curlew Sandpiper in 2004 and 2006 were calculated on the assumption that peak numbers counted only at Zuidong represented a third of the staging population in the entire core study area (of which Zuidong is approximately one third). We also assumed that 2004 followed on 2000-2002 and that 2006 followed on 2004.

\section{Results}

The recent history of loss of intertidal land

According to analysis of the remote sensing images from 1974 to 1993 , a total of $313 \mathrm{~km}^{2}$ of intertidal area was reclaimed mainly for salt works in Tianjin and Tangshan along western 
and northern Bohai Bay. In the following 16 years (1994-2010), approximately $450 \mathrm{~km}^{2}$ of offshore area, including $218 \mathrm{~km}^{2}$ of intertidal mudflats (34\% of the total intertidal area in 1993 in western and northern Bohai Bay) was reclaimed for the Tianjin Binhai and Caofeidian New Areas (Figs. 2 and 3). Notably, reclamation accelerated during the past five years (2005-2010) with a removal of $78 \%$ of the total reclaimed tidal area for the two developments (Figs. 2, 3 and 4 ). The Tianjin Binhai and Caofeidian New Areas had reclaimed a total of $110 \mathrm{~km}^{2}$ and $108 \mathrm{~km}^{2}$ intertidal lands, respectively, by 2010 .

\section{Abundance of waterbirds in Tianjin and Tangshan}

A total of 58 waterbird species were recorded in the study areas of Tianjin and Tangshan during the study (Fig. I, Table 2). Sixteen of them occurred in internationally important concentrations in the study region: 14 species during northward migration and four species during southward migration and winter. During the survey periods, shorebirds and gulls comprised most of the waterbirds occurring in the intertidal area. Shorebirds clearly formed the great majority, accounting for $99 \%$ of all waterbirds in May, $75 \%$ in winter and $66 \%$ in September.

\section{Spring counts (2007-2010)}

At the beginning of the survey period in $2006 / 2007$, the spring density of waterbirds on mudflats in Tangshan was higher than that in Tianjin (Table 3). With the ongoing losses of intertidal habitats in western and northern Bohai Bay, densities of waterbirds increased dramatically during the subsequent springs, while densities in the rapidly disappearing study area in Tianjin declined from 2007 to 2008 (Table 3). Red Knot, Curlew Sandpiper, Broad-billed Sandpiper Limicola falcinellus and Sanderling Calidris alba increased rapidly at the study sites in Tangshan over the years, as the loss of intertidal mudflats in Bohai Bay continued.

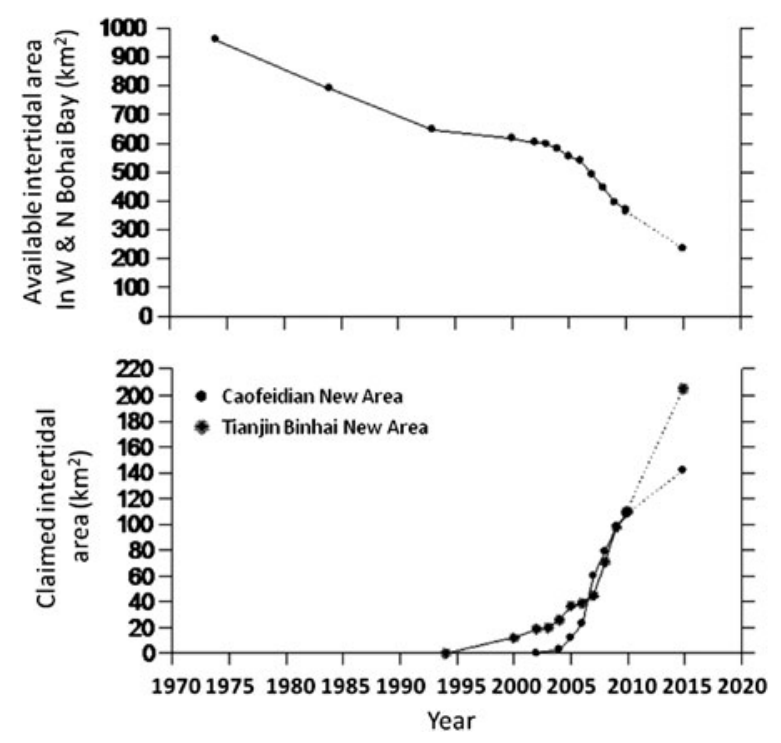

Figure 3. Changes in the available intertidal area in Tianjin and Tangshan along western and northern Bohai Bay from 1974 to 2015 (above) and changes in the reclaimed intertidal area due to the Tianjin Binhai and Caofeidian New Areas respectively from 1994 to 2015 (below). The dotted lines present the possible situation according to the plan of the Tianjin Binhai and Caofeidian New Areas. 


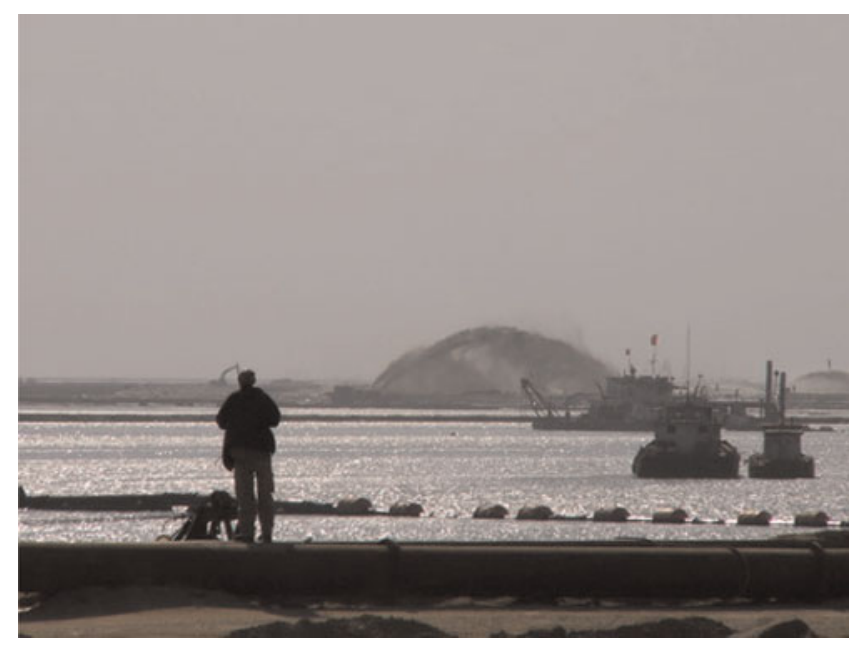

Figure 4. Land reclamation activity on the mudflats in Caofeidian New Area in spring 2007.

\section{Winter counts (2006/2007 to 2009/2010)}

Since the start of winter counts in 2006/2007, the density of waterbirds underwent a rapid increase in both Tianjin and Tangshan, concurrent with the rapid loss of tidal flats in the surrounding area (Table 4, Fig. 2). Although waterbird densities in Tangshan were relatively stable from 2007/2008 to 2008/2009, they decreased during 2009/2010, a rather severe winter (Table 4). With the exception of this last cold winter, waterbird populations increased at the study sites, mainly due to the large influx of Eurasian Curlews and Relict Gulls, which were the most common wintering waterbirds (Fig. 5). The peak count of wintering Eurasian Curlews in the core study area in Tangshan increased from $6 \%$ of the flyway population in 2006 to $17 \%$ in 2009; for Relict Gull the proportion of the global population increased from 6\% in 2006 to $61 \%$ in 2009.

\section{Seasonal changes in shorebird numbers in Tangshan between 2004 and 2009}

The only count sector that was comprehensively covered by monthly surveys in both 2004 and 2009 was Zuidong (Fig. I). The seasonal pattern of change in shorebird abundance was similar in 2004 and 2009, with a large peak occurring during northward migration in both years (Fig. 6). However, compared to the 2004 survey, which was carried out before the tidal flat reclamation in Tangshan, the densities of shorebirds in this sector substantially increased during northward migration 2009 (Fig. 6), especially in the three species for which this area is of special importance in flyway terms: Sanderling ( $11 \%$ of their flyway population on 24 May 2009), Eurasian Curlew ( $8.7 \%$ on 3 February 2009) and Red Knot (8.5\% on 10 May 2009); the $1 \%$ criterion of Eurasian Curlew and Red Knot follow Bamford et al. (2008) to compare with the percentage in 2004 (Yang et al. 2008).

\section{Changes in predicted and observed numbers of Red Knot and Curlew Sandpiper in Tangshan between 2002 and 2010}

In the core study area in Tangshan, the peak counts of Red Knot and Curlew Sandpiper increased dramatically from $13 \%$ and $3 \%$ of their flyway populations in 2007 to $62 \%$ and $23 \%$ in 2010 , respectively. As shown in Fig. 7, increasing numbers of Red Knot and Curlew Sandpiper, the two 
Table 2. Waterbird species and their maximum numbers recorded in Tianjin and Tangshan during the study. Species are listed in order of abundance. "IUCN" shows the conservation status of each species; " $1 \%$ " indicates species whose maximum number was more than $1 \%$ of their estimated flyway population (Wetlands International 2006, Bamford et al. 2008, Cao et al. 2009, Rogers et al. 2010, IUCN 2010 and BirdLife International 2011).

\begin{tabular}{|c|c|c|c|c|c|c|}
\hline \multicolumn{2}{|l|}{ Species } & \multirow{2}{*}{$\begin{array}{l}\text { Period of } \\
\text { presence }^{\text {a }}\end{array}$} & \multicolumn{2}{|c|}{ Maximum number } & \multirow[t]{2}{*}{$\mathrm{IUCN}^{\mathrm{b}}$} & \multirow[t]{2}{*}{$1 \%$} \\
\hline English name & Scientific name & & Number & Date & & \\
\hline Red Knot & Calidris canutus & M & 64958 & May-10 & LC & $>$ \\
\hline Curlew Sandpiper & Calidris ferruginea & M & 40730 & May-1o & LC & $>$ \\
\hline Eurasian Curlew & Numenius arquata & $\mathrm{W}, \mathrm{M}$ & 18006 & Feb-o9 & NT & $>$ \\
\hline Red-necked Stint & Calidris ruficollis & M & 11522 & May-o8 & LC & $>^{c}$ \\
\hline Dunlin & Calidris alpina & $\mathrm{W}, \mathrm{M}$ & 9950 & May-09 & LC & $>$ \\
\hline Relict Gull & Larus relictus & W, M & 8477 & Jan-o9 & VU & $>^{c}$ \\
\hline Great Knot & Calidris tenuirostris & M & 7613 & May-07 & VU & $>^{c}$ \\
\hline Black-headed Gull & Larus ridibundus & $\mathrm{W}, \mathrm{M}$ & 7031 & Sep-o6 & LC & \\
\hline Kentish Plover & Charadrius alexandrinus & M, B & 6910 & Мay-ıo & $\mathrm{LC}$ & $>$ \\
\hline Broad-billed Sandpiper & Limicola falcinellus & M & 5280 & May-09 & LC & $>$ \\
\hline Sharp-tailed Sandpiper & Calidris acuminata & M & 5242 & May-09 & LC & $>^{c}$ \\
\hline Grey Plover & Pluvialis squatarola & $\mathrm{W}, \mathrm{M}$ & 4340 & Dec-07 & $\mathrm{LC}$ & $>$ \\
\hline Pied Avocet & Recurvirostra avosetta & M, B & 3167 & Sep-o8 & LC & $>$ \\
\hline Sanderling & Calidris alba & M & 2430 & May-09 & LC & $>$ \\
\hline Common Shelduck & Tadorna tadorna & $\mathrm{W}, \mathrm{M}$ & 2350 & Dec-07 & LC & $>$ \\
\hline Marsh Sandpiper & Tringa stagnatilis & M & 2290 & May-10 & LC & $>$ \\
\hline Bar-tailed Godwit & Limosa lapponica & M & 1679 & May-o8 & LC & \\
\hline Herring Gull & Larus argentatus & $\mathrm{W}, \mathrm{M}$ & 818 & Sep-o6 & LC & \\
\hline Mew Gull & Larus canus & $\mathrm{W}, \mathrm{M}$ & 790 & Jan-o8 & LC & \\
\hline Asian Dowitcher & Limnodromus semipalmatus & M & 755 & May-o8 & NT & $>^{c}$ \\
\hline Black-tailed Gull & Larus crassirostris & $\mathrm{W}, \mathrm{M}$ & 634 & Sep-o7 & LC & \\
\hline Black-tailed Godwit & Limosa limosa & M & 533 & Sep-o8 & NT & \\
\hline Oriental Pratincole & Glareola maldivarum & M & 510 & Sep-o6 & LC & \\
\hline Mallard & Anas platyrhynchos & $\mathrm{W}$ & 400 & Feb-o9 & LC & \\
\hline Common Greenshank & Tringa nebularia & M & 399 & Sep-o6 & LC & \\
\hline Slaty-backed Gull & Larus schistisagus & $\mathrm{W}, \mathrm{M}$ & 359 & Sep-o8 & LC & \\
\hline Lesser Sand Plover & Charadrius mongolus & M & 336 & May-08 & LC & \\
\hline Common Tern & Sterna hirundo & M & 331 & May-07 & LC & \\
\hline Ruddy Turnstone & Arenaria interpres & M & 211 & May-07 & LC & \\
\hline Gull-billed Tern & Sterna nilotica & M & 192 & May-08 & $\mathrm{LC}$ & \\
\hline Little Egret & Egretta garzetta & $\mathrm{M}$ & 170 & Sep-o6 & LC & \\
\hline Grey Heron & Ardea cinerea & M & 162 & Sep-o7 & LC & \\
\hline Little Tern & Sterna albifrons & $\mathrm{M}, \mathrm{B}$ & 95 & May-10 & LC & \\
\hline Terek Sandpiper & Xenus cinereus & M & 73 & May-08 & LC & \\
\hline Whimbrel & Numenius phaeopus & $\mathrm{M}$ & 70 & May-07 & LC & \\
\hline Black-winged Stilt & Himantopus himantopus & M & 68 & May-07 & LC & \\
\hline Saunders's Gull & Larus saundersi & $\mathrm{W}, \mathrm{M}$ & 56 & Dec-o6 & VU & \\
\hline Far Eastern Curlew & Numenius madagascariensis & M & 54 & May-o8 & VU & \\
\hline Pacific Golden Plover & Pluvialis fulva & M & 32 & May-08 & LC & \\
\hline Caspian Tern & Sterna caspia & M & 26 & Sep-o6 & $\mathrm{LC}$ & \\
\hline Spotted Redshank & Tringa erythropus & $\mathrm{M}$ & 19 & Sep-o8 & LC & \\
\hline Common Redshank & Tringa totanus & M & 18 & May-07 & LC & \\
\hline Common Sandpiper & Actitis hypoleucos & M & 14 & Sep-o7 & LC & \\
\hline Long-billed Dowitcher & Limnodromus scolopaceus & M & 10 & May-09 & LC & \\
\hline Little Stint & Calidris minuta & M & 4 & May-10 & LC & \\
\hline Wood Sandpiper & Tringa glareola & M & 3 & May-09 & LC & \\
\hline Little Curlew & Numenius minutus & M & 3 & May-10 & $\mathrm{LC}$ & \\
\hline
\end{tabular}


Table 2. Continued.

\begin{tabular}{|c|c|c|c|c|c|c|}
\hline \multicolumn{2}{|l|}{ Species } & \multirow{2}{*}{$\begin{array}{l}\text { Period of } \\
\text { presence }^{\mathrm{a}}\end{array}$} & \multicolumn{2}{|c|}{ Maximum number } & \multirow{2}{*}{\multicolumn{2}{|c|}{$\mathrm{IUCN}^{\mathrm{b}}$}} \\
\hline English name & Scientific name & & Number & Date & & \\
\hline Great Egret & Casmerodius albus & $\mathrm{M}$ & 3 & Sep-o7 & $\mathrm{LC}$ & \\
\hline Cattle Egret & Bubulcus ibis & M & 3 & May-07 & $\mathrm{LC}$ & \\
\hline Spotted Greenshank & Tringa guttifer & M & 2 & May-ıo & EN & \\
\hline Ruff & Philomachus pugnax & M & 2 & May-o8 & LC & \\
\hline Greater Sand Plover & Charadrius leschenaultii & M & 2 & May-07 & LC & \\
\hline Grey-tailed Tattler & Heteroscelus brevipes & M & 1 & May-07 & LC & \\
\hline Eurasian Oystercatcher & Haematopus ostralegus & $\mathrm{W}, \mathrm{M}$ & 1 & May-07 & $\mathrm{LC}$ & \\
\hline Grey-headed Lapwing & Vanellus cinereus & M & 1 & May-o8 & LC & \\
\hline Glaucous Gull & Larus hyperboreus & W & 1 & Jan-o9 & $\mathrm{LC}$ & \\
\hline Chinese Egret & Egretta eulophotes & $\mathrm{M}$ & 1 & May-o7 & VU & \\
\hline Chinese Pond Heron & Ardeola bacchus & M & 1 & May-o7 & LC & \\
\hline
\end{tabular}

${ }^{a} \mathrm{~W}, \mathrm{M}$ and $\mathrm{B}$ are winter, migration and breeding period respectively ${ }^{\mathrm{b}} \mathrm{LC}$ - Least Concern, NT - Near Threatened, VU - Vulnerable, EN - Endangered, as listed by IUCN (2010) ${ }^{c}$ the flyway population is the world population.

most common migrant shorebirds during northward migration, could partially be accounted for by displacement of birds from lost areas. That the predicted increases are smaller than the actual increases should not surprise us, as many areas were not counted previously at the peak period (Barter et al. 2001, 2003). The general pattern of increase is consistent with the idea that over the course of the years, as more mudflat areas in Bohai Bay were reclaimed, the staging populations became ever more concentrated in what remained, as shown directly for Red Knot (Fig. 8). In 2010, with 970 birds $\mathrm{km}^{-2}$, the density of Red Knot was four times higher than in the years up to 2007 (211 birds $\mathrm{km}^{-2}$ ) in the core study area.

\section{Discussion}

The Yellow Sea is a critical stopover site for waterbirds in the EAAF (Barter 2002, Minton et al. 2006). The large numbers and diversity of waterbirds in the present study area during migration periods (especially during northward migration) and in winter confirm the critical importance of the Bohai Bay coast for migrating waterbirds. Bohai Bay supports high proportions of the flyway populations of Relict Gull, Red Knot, Broad-billed Sandpiper, Curlew Sandpiper and Eurasian Curlew (Table 2). With the current rapid economic growth in China leading to increasing human populations and industrial projects in coastal areas, habitat loss resulting from wetland reclamation remains a major threat for biodiversity conservation.

During 1994-2010 one third of the intertidal mudflats in the western and northern Bohai Bay system were lost to industrial development, with the speed of land reclamation actually

Table 3. Changes in the available intertidal area along western and northern Bohai Bay and waterbird densities in May in the study areas in Tianjin and Tangshan from 2007 to 2010.

\begin{tabular}{|c|c|c|c|c|c|c|}
\hline \multirow[t]{2}{*}{ Period } & \multirow{2}{*}{$\begin{array}{l}\text { Average } \\
\text { temperature } \\
\left({ }^{\circ} \mathrm{C}\right)^{\text {a }}\end{array}$} & \multirow{2}{*}{$\begin{array}{l}\text { Retained } \\
\text { mudflats in } \\
\text { W \& N Bohai } \\
\text { Bay }\left(\mathrm{km}^{2}\right)\end{array}$} & \multicolumn{2}{|c|}{$\begin{array}{l}\text { Average mudflats } \\
\text { surveyed }\left(\mathrm{km}^{2}\right)\end{array}$} & \multicolumn{2}{|c|}{$\begin{array}{l}\text { Average density of } \\
\text { waterbirds }\left(\mathrm{bird} / \mathrm{km}^{2}\right)\end{array}$} \\
\hline & & & Tianjin & Tangshan & Tianjin & Tangshan \\
\hline 2007 & 19.4 & 492 & 46 & 67 & 252 & 292 \\
\hline 2008 & 17.8 & 447 & 14 & 67 & 145 & 574 \\
\hline 2009 & 20.6 & 396 & - & 59 & - & 755 \\
\hline 2010 & 18.4 & 370 & - & 67 & - & 961 \\
\hline
\end{tabular}

${ }^{a}$ Average temperature in May in Tangshan (CMDSSS 2010) 
Table 4. Changes in the available intertidal area along western and northern Bohai Bay, densities of waterbirds and of the two main groups (shorebirds and gulls) in winter (December, January and February) in the study areas in Tianjin and Tangshan from 2006 to 2010.

\begin{tabular}{|c|c|c|c|c|c|c|c|c|c|c|c|}
\hline \multirow[t]{2}{*}{ Period } & \multirow[t]{2}{*}{$\begin{array}{l}\text { Average } \\
\text { temperature } \\
\text { in Tianjin }\left({ }^{\circ} \mathrm{C}\right)^{\text {a }}\end{array}$} & \multirow{2}{*}{$\begin{array}{l}\text { Average } \\
\text { temperature } \\
\text { in Tangshan } \\
\left({ }^{\circ} \mathrm{C}\right)^{\text {a }}{ }^{\text {a }}\end{array}$} & \multirow{2}{*}{$\begin{array}{l}\text { Retained } \\
\text { mudflats in } \\
\text { W \& N Bohai } \\
\text { Bay }\left(\mathrm{km}^{2}\right)\end{array}$} & \multicolumn{2}{|c|}{$\begin{array}{l}\text { Average mudflats } \\
\text { surveyed }\left(\mathrm{km}^{2}\right)\end{array}$} & \multicolumn{2}{|c|}{$\begin{array}{l}\text { Average density of } \\
\text { waterbirds (birds } \\
\mathrm{km}^{-2} \text { ) }\end{array}$} & \multicolumn{2}{|c|}{$\begin{array}{l}\text { Average density of } \\
\text { shorebirds (birds } \\
\mathrm{km}^{-2} \text { ) }\end{array}$} & \multicolumn{2}{|c|}{$\begin{array}{l}\text { Average density of } \\
\text { gulls (birds } \mathrm{km}^{-2} \text { ) }\end{array}$} \\
\hline & & & & Tianjin & Tangshan & Tianjin & Tangshan & Tianjin & Tangshan & Tianjin & Tangshan \\
\hline 2006-2007 & -0.4 & -0.2 & 492 & 46 & 67 & 24 & 85 & 5 & 68 & 19 & 10 \\
\hline $2007-2008$ & -1.4 & -1.6 & 447 & 25 & 43 & 112 & 269 & 38 & 225 & 70 & 25 \\
\hline $2008-2009$ & -1.4 & -1.5 & 396 & 12 & 67 & 326 & 247 & 234 & 174 & 90 & 59 \\
\hline 2009-2010 & $-3 \cdot 3$ & -3.2 & 370 & - & 56 & - & 88 & - & 83 & - & 5 \\
\hline
\end{tabular}

${ }^{a}$ Average temperature in winter months (December, January and February) in Tianjin and Tangshan (CMDSSS 2010) 

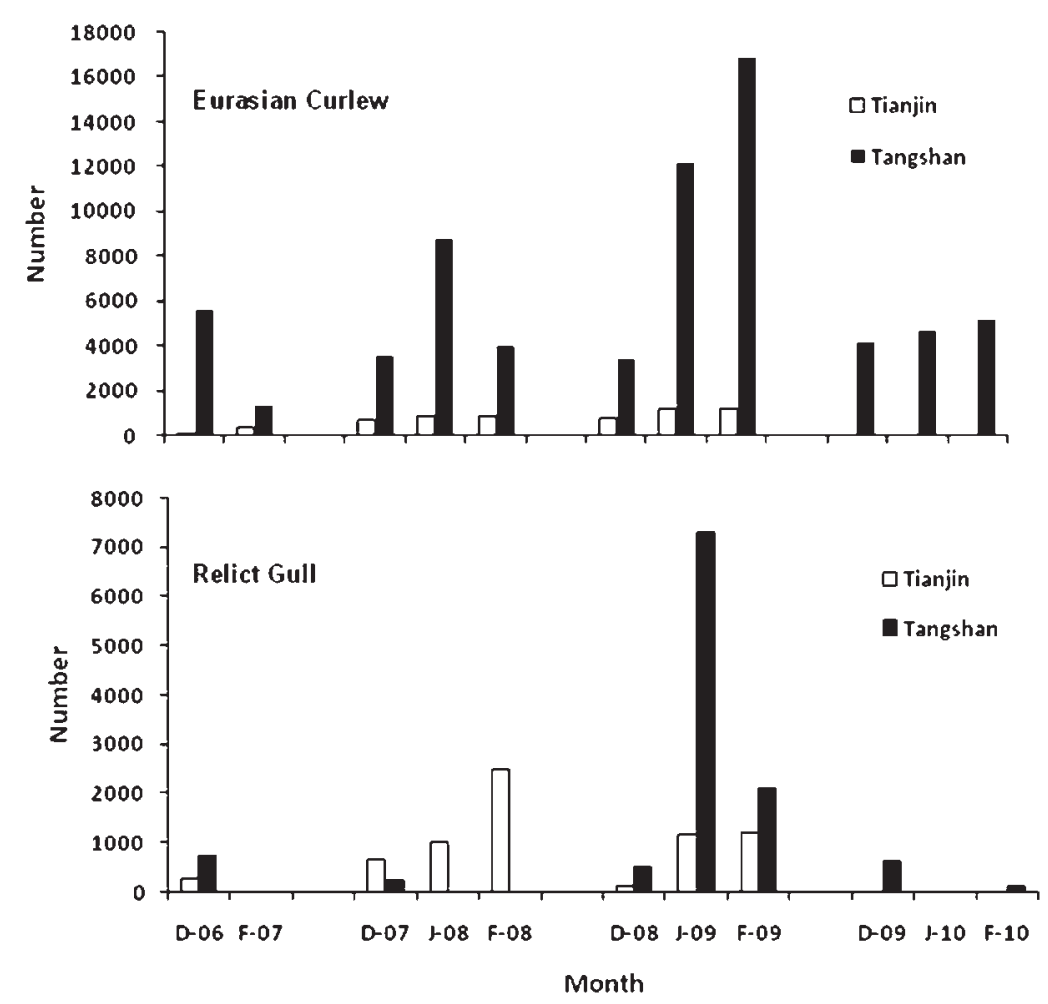

Figure 5. Monthly numbers of Eurasian Curlew and Relict Gull, two main species, at study sites in Tianjin and Tangshan during winter months from 2006 to 2010 (the remaining study sites in Tianjin were not surveyed in the last winter). Average mudflats surveyed in Tianjin and Tangshan in each winter showed in Table 4. 1 \% of the flyway population of Eurasian Curlew is 1,000 birds (Cao et al. 2009) and that of the world population of Relict Gull is 120 birds (Wetlands International 2006, BirdLife International 2010a). D, J and F are December, January and February, respectively.

accelerating since 2006. What would happen if the intertidal habitats continued to decrease? Would the number of waterbirds in Bohai Bay be reduced or would they move to nearby remaining wetland? From 2007 to 2010 the populations of waterbirds, especially shorebirds, noticeably increased in the core study sites in Tangshan (Beipu, Nanpu and Zuidong) that were not much affected by reclamation schemes (Tables 3, 4). The increase in shorebird numbers at Zuidong has been going on since at least 2004 when the main reclamations began (Fig. 6; Yang et al. 2008). Meanwhile, Red Knot and Curlew Sandpiper, the two main species during northward migration, continued to concentrate in the core area in Tangshan as land reclamation continued in Bohai Bay (Figs. 7 and 8). This suggests that birds moved from the lost mudflats to what was left nearby; it may also mean that they have nowhere else to go.

Two subspecies of Red Knot, C. c. piersmai and C. c. rogersi, stage at the intertidal mudflats of Bohai Bay. According to the peak counts, by 2010 at least $67 \%$ of the world population of $C$. c. piersmai and $57 \%$ of C. c. rogersi, based on the figures in Rogers et al. (2010) refuelled at the core study sites for several weeks in April and May. The increase in Red Knot numbers counted is actually accompanied by decreases in the total flyway population of the two subspecies, from c.222,00o birds in 2000 (Bamford et al. 2008) to 130,000 birds in 2007 (Piersma 2007) to 105,000 birds in 2009 (Rogers et al. 2010). Similarly, Curlew Sandpiper on their wintering grounds in 


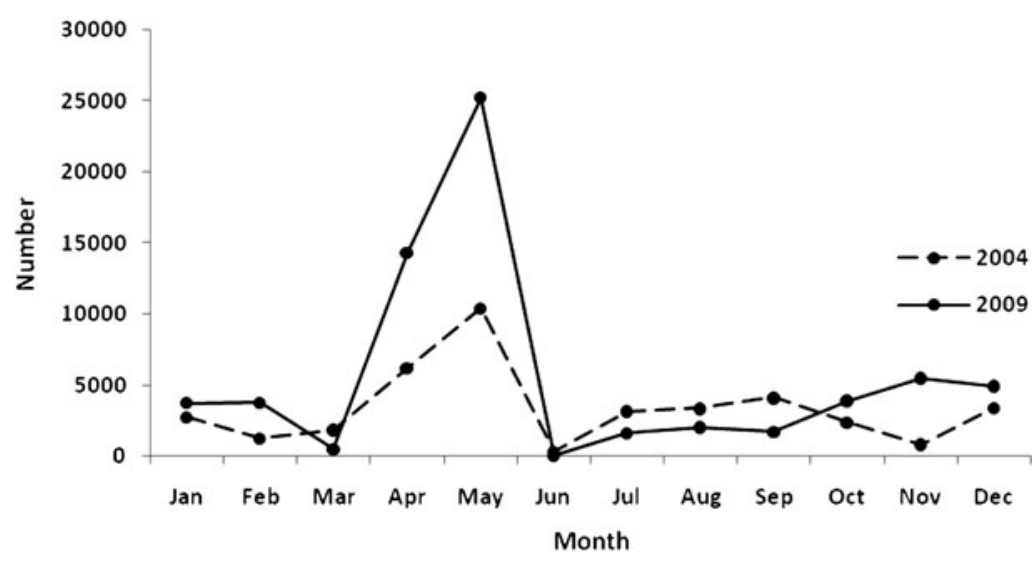

Figure 6. Maximum monthly numbers of shorebirds at Zuidong in Tangshan (including $22 \mathrm{~km}^{2}$ of intertidal flats) in 2004 and 2009 (2004 data from Yang et al. 2008).

Australia have also shown decreasing numbers over 30 years (Gosbell and Clemens 2006, Rogers and Gosbell 2006a, C. Minton unpubl. data). Therefore, our study confirms the prediction that birds are forced into ever smaller areas of tidal flat in Bohai Bay during northward migration.

A large proportion of the world's declining population of Relict Gull numbering 12,000 birds (BirdLife International 2010a, IUCN 2010) winters in Bohai Bay. The Tianjin coast was
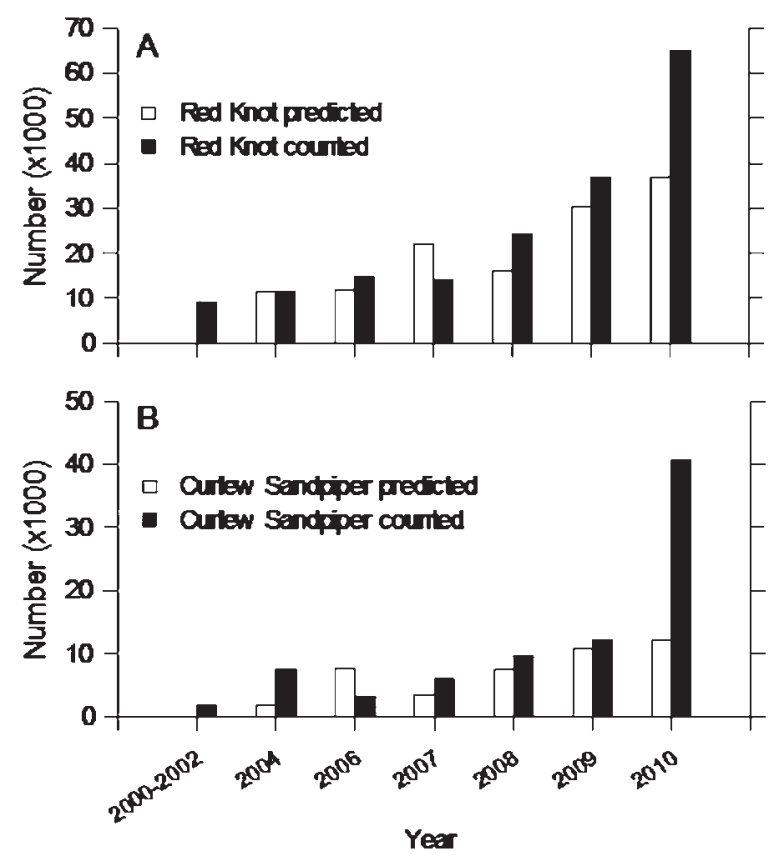

Figure 7. Predicted and counted peak numbers of Red Knot (A) and Curlew Sandpiper (B) in the core study area (Beipu, Nanpu and Zuidong) (including $67 \mathrm{~km}^{2}$ of tidal flats) in Tangshan during northward migration from 2000 to 2010 . The white and black bars give the predicted and counted peak numbers at the core study sites in 2000-2002, 2004 and 2006-2010 respectively. 


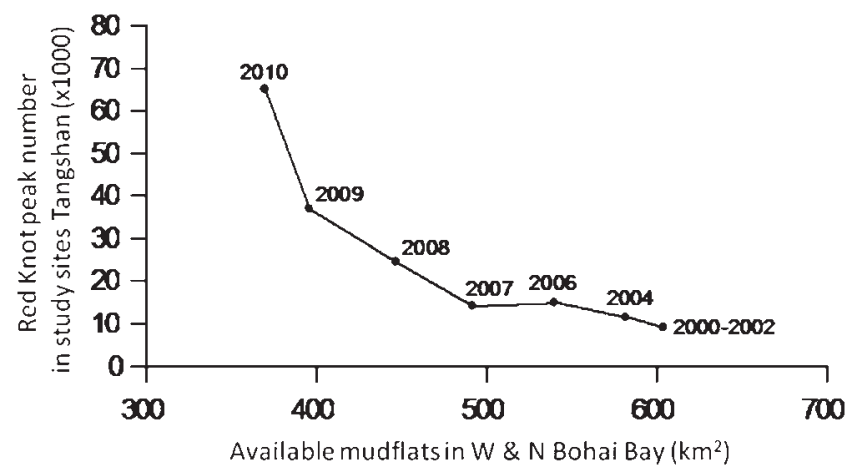

Figure 8. Changes in peak numbers of Red Knot in the core study area in Tangshan (Beipu, Nanpu and Zuidong) in parallel with changes in the available intertidal area in Tianjin and Tangshan along western and northern Bohai Bay during northward migration from 2000 to 2010.

previously the most important known wintering ground, especially for adults (Liu et al. 2006). Interestingly, the largest number of Relict Gulls occurred in Tianjin $(8,230$ birds, of which 7,880 birds were found in the Jingqu sub-area, south of the Duliujian estuary and not part of our study area; Fig. 1) on 17 December 2005 at the beginning of the severe 2005/2006 winter (Fig. 9) when exposed mudflats were still available (Y. Liu unpubl. data). However, the importance of Tianjin has decreased since late 2007, as much of the traditional wintering habitat has been converted into land for industrial development. In the 2008/2009 winter they had apparently moved to Tangshan where they were found in good numbers ( 7,318 birds, $61 \%$ of their global population, in January 2009), coinciding with habitat loss in Jingqu (Fig. 2), which held the largest number of Relict Gulls counted in Tianjin. The number of Relict Gulls present in our remaining study sites in Tianjin and Tangshan in the 2008-2009 winter (8,477 birds) matched the previous maximum winter count in Tianjin $(8,230$ birds in 2005, Y. Liu unpubl. data). That Relict Gull numbers were so much lower during the following winter (Fig. 5) must have been due to this winter being the most severe in Bohai Bay for 30 years (Fig. 9). Weather conditions have previously affected the winter distribution of Relict Gull (Liu et al. 2006, BirdLife International 2010a). We suggest that the Tangshan intertidal area has become the most important wintering ground for Relict Gull in normal winters.

Eurasian Curlew is now listed as 'Near Threatened' (BirdLife International 2010b, IUCN 2010) and according to an updated estimate, their EAAF population is now 100,000 birds (Cao et al. 2009). The difference between the new estimate and the old one of 40,000 birds (Bamford et al. 2008) can be explained by the inclusion of previously unknown numbers of birds wintering in China but not an increase in the flyway population. Eurasian Curlew winter on the coasts of the EAAF and the most northerly and abundant area is Bohai Bay (Cao et al. 2009). In normal winters from 2006/2007 to 2008/2009, Eurasian Curlew numbers increased rapidly in the Tangshan study area (Fig. 5), possibly because previously important wintering areas nearby were reclaimed by Caofeidian New Area (H.Y. Yang unpubl. data; Fig. 2). That 4,000-5,000 Eurasian Curlews stayed for the whole of the coldest winter in 30 years shows that this small area of intertidal mudflats in Tangshan is very attractive (Figs. 5 and 9).

\section{Ongoing land developments and predicted effects on waterbirds}

A new big industrial development, Cangzhou Bohai New Area, has been under development in south-western Bohai Bay since 2007, with $3,321 \mathrm{~km}^{2}$ of planned developments including a 117 $\mathrm{km}^{2}$ offshore area (SOAPRC 2009). According to the land reclamation plans (Table 1 ) and the 


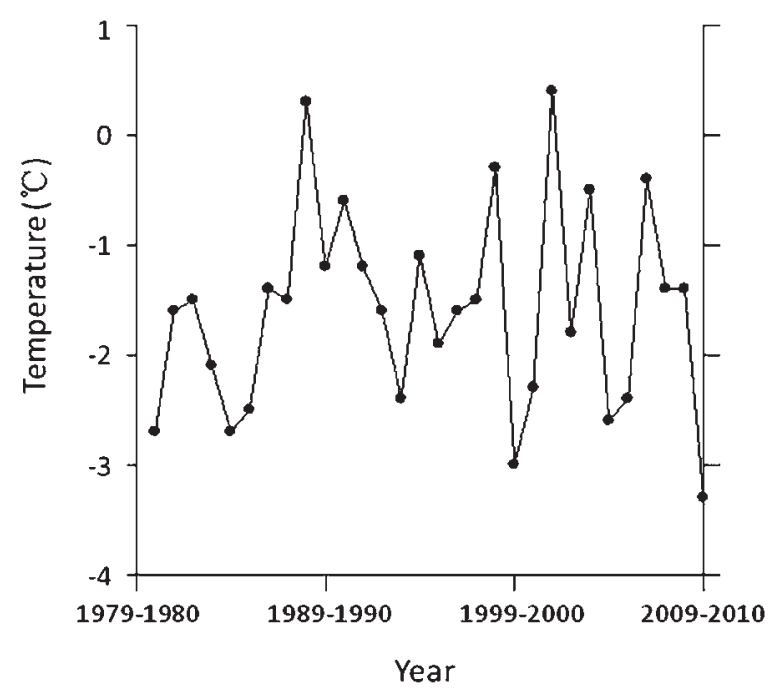

Figure 9. Average winter temperatures (December, January, February) in Tianjin from 1980/ 1981 to 2009/2010 (CMDSSS 2010). We used the average winter temperature in Tianjin as the temperature is similar in the two areas (Table 4$)$.

presence of sea walls still to be closed (pers. obs.), more marine habitats, including large areas of intertidal mudflat, will soon be lost at all three development project sites. In addition, the local government has started other small reclamation projects in the core study area, which affect intertidal areas by direct land conversion as well as the pumping of sand to fill-in near-shore saltpans (Fig. 10).

We suggest that waterbird densities at the remaining coastal sites in Bohai Bay, especially in Tangshan, will continue to increase as intertidal flats are lost. As a result, the survival of birds forced to congregate together or to relocate is likely to decrease, leading to a decline in their flyway populations (Evans et al. 1979, Goss-Custard 1980, Baker et al. 2004, Burton et al. 2006, Goss-Custard et al. 2006).

If the entire intertidal area in Bohai Bay disappears, what will happen to the waterbirds that depend on it now? Along the Yellow Sea coastline, mudflats are being lost at great speed (Barter 2002, Moores 2006, Moores et al. 2008, SOAPRC 2009, Wan et al. 2009), and it is believed that declines in migratory shorebird populations in Australia and New Zealand over the last 30 years (Gosbell and Clemens 2006, Southey 2009, C. Minton unpubl. data, AWSG and Arthur Rylah Institute unpubl. data) are due to the loss of feeding habitat at stopovers along the Yellow Sea

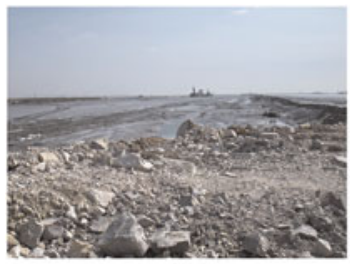

A

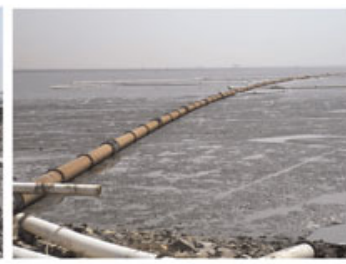

B

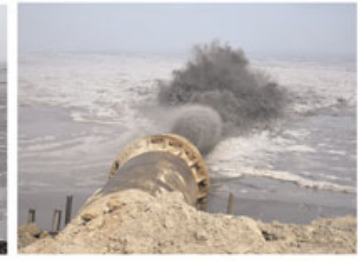

C

Figure 10. Reclamation activities at Zuidong, one of the core study sites in Tangshan, since 2009 for industry. A shows land reclamation on the mudflats. $B$ and $C$ are the pumping of sand from the mudflats (B) to fill-in near-shore saltpans (C). 
coast (Barter 2005, Gosbell and Clemens 2006, C. Minton and D. Rogers pers. comm.). That the Yellow Sea may well be filled to capacity is demonstrated by the declines between 2006 and 2008 in 19 of the most abundant shorebird species at Saemangeum (137,000 shorebirds in total; Moores et al. 2008), a recently reclaimed intertidal area in South Korea that was previously the premier shorebird site in the Yellow Sea (Moores 2006, Rogers et al. 2006b). Among them was the Great Knot Calidris tenuirostris, endemic to this flyway, of which $23 \%$ of the population depended on Saemangeum during northward migration (Rogers et al. 2006b, Moores et al. 2008). Since the Saemangeum mudflats were closed off, the world population has declined by $20 \%$ (Moores et al. 2008) resulting in Great Knot now being assessed as 'Vulnerable' by IUCN (2010) and BirdLife International (2010c). Apparently, this unique shorebird species had nowhere else to go.

In view of the agreements between China and Japan (Beijing-1981), and China and Australia (Canberra-1988) to safeguard migratory birds and their environments (Anon. 1981, 1988), China should protect the remaining intertidal areas within Bohai Bay to limit further declines in waterbird populations within the EAAF. Additionally, in order to monitor the effects of tidal flat reclamation on waterbirds, systematic surveys should be conducted, especially during the winter and northward migration periods. Also, more research should be carried out to develop a good understanding of the relationship between mudflats, benthos and waterbirds to understand the unique ecosystem in Bohai Bay that supports such large waterbird numbers. It is also important that decision makers and the public are made fully aware of the great importance of Bohai Bay for waterbirds, and of the potential environmental disaster for all those that rely on the tidal flats as a food source, including the many human beings that harvest the Bay's finfish and shellfish (Kim et al. 2006, Sato 2006, Nie and Tao 2008, Wan et al. 2009).

\section{Acknowledgements}

This project was supported by National Basic Research Program of China (Grant No. 2006CB403305), National Natural Science Foundation of China-Guangdong Joint Fund (Grant No. Uo833005) and the National Fish and Wildlife Foundation-ConocoPhillips SPIRIT of Conservation Migratory Bird Program and the International Crane Foundation. We acknowledge the support for our field research from Ming-Lu Wu, Section Chief of the Forestry Department, Hebei Province, China. We thank Ru-Lin Gao for his enthusiastic guiding to most of the study sites in Tangshan and his generosity in sharing his local knowledge. We thank Rui-Ding Zhao, Biao Wang, Xue-Song Feng, Dong-Lai Li, Si-Hang Chen, Jian-Qiang Li, Ning Wang, Lei Guan, Yang Qiu, Wei-Pan Lei, Si-Hai Yan, Tian Fang, Lan Zhang and Xiao-Jing Li for field assistance and Dong-Lai Li for helping draw the map of study sites. The manuscript was improved with help from anonymous reviewers, Phil Battley, Clive Minton and Phil Atkinson.

\section{References}

Amano, T., Székely, T., Koyama, K., Amano, H. and Sutherland, W. J. (2010) A framework for monitoring the status of populations: An example from wader populations in the East Asian-Australasian flyway. Biol. Conserv. 143: 2238-2247.

Anon (1981) Agreement between the Government of Japan and the Government of the People's Republic of China for the Protection of Migratory Birds and their Environment, Beijing. (In Chinese). http:// biodiv.coi.gov.cn/fg/gy/o7.htm (accessed on 8 April 2010)
Anon (1988) Agreement between the Government of Australia and the Government of the People's Republic of China for the Protection of Migratory Birds and their Environment. Australian Treaty Series 1988 No. 22, Australian Government Publishing Service, Canberra. http://www. austlii.edu.au/au/other/dfat/treaties/1988/ 22.html (accessed on 8 April 2010)

Baker, A. J., González, P. M., Piersma, T., Niles, L. J., de Lima Serrano do Nascimento, I., Atkinson, P. W., Collins, P., Clark, N. A., Minton, C. D. T., Peck, M. K. and Aarts, G. 
(2004) Rapid population decline in Red Knots: fitness consequences of decreased refuelling rates and late arrival in Delaware Bay. Proc. R. Soc. Lond B 271: 875-882.

Bamford, M., Watkins, D., Bancroft, W., Tischler, G. and Wahl, J. (2008) Migratory shorebirds of the East Asian - Australasian flyway; population estimates and internationally important sites. Canberra, Australia: Wetlands International - Oceania.

Barter, M. A. (2002) Shorebirds of the Yellow Sea: Importance, threats and conservation status. Canberra, Australia: Wetlands International. (Wetlands International Global Series 9/International Wader Studies 12).

Barter, M. A. (2005). Yellow Sea-driven priorities for Australian shorebird researchers. Pp 158-160 in Proceedings of the Australasian Shorebirds Conference, 13-15 December, 2003, Canberra, Australia. Sydney, Australia: Wetlands International. (Wetlands International Global Series 18/ International Wader Studies 17).

Barter, M. A., Li, Z. W. and Xu, J. L. (2001) Shorebird numbers on the Tianjin municipality coast in May 2000. Stilt 39: 2-9.

Barter, M. A., Riegen, A. and Xu, Q. (2003) Shorebird numbers in Bohai Wan during northward migration. Stilt 44: 3-8.

Battley, P. F., Rogers, D. I., van Gils, J. A., Piersma, T., Hassell, C. J., Boyle, A. and Yang, H. Y. (2005) How do Red Knots Calidris canutus leave Northwest Australia in May and reach the breeding grounds in June? Predictions of stopover times, fuelling rates and prey quality in the Yellow Sea. J. Avian Biol. 36: 494-500.

BirdLife International (2004) Important Birds Areas in Asia: Key sites for conservation. Cambridge, UK: BirdLife International. (BirdLife Conservation Series No. 13).

BirdLife International (2010a) Species factsheet: Relict Gull Larus relictus. http://www. birdlife.org/datazone/speciesfactsheet.php? id $=3246$ (accessed on 22 October 2010)

BirdLife International (2010b) Species factsheet: Eurasian Curlew Numenius arquata. http:// www.birdlife.org/datazone/speciesfactsheet. php? id $=3012$ (accessed on 3 January 2011)

BirdLife International (2010c) Species factsheet: Great Knot Calidris tenuirostris. http://www.birdlife.org/datazone/species- factsheet.php?id=3040 (accessed on II July 2010)

BirdLife International (2011) BirdLife Data Zone. http://www.birdlife.org/datazone/home (accessed on 20 February 2011)

Burton, N. H. K., Rehfisch, M. M., Clark, N. A. and Dodd, S. G. (2006) Impacts of sudden winter habitat loss on the body condition and survival of redshank Tringa totanus. J. Appl. Ecol. 43: 464-473.

Cao, L., Tang, S., Wang, X. and Barter, M. A. (2009) The importance of eastern China for shorebirds during the non-breeding season. Етu 109: 170-178.

Catry, T., Alves, J. A., Andrade, J., Costa, H., Dias, M. P., Fernandes, P., Leal, A., Lourenço, P. M., Martins, R. C., Moniz, F., Pardal, S., Rocha, A., Santos, C. D., Encarnação, V. and Granadeiro, J. P. (In press) Long-term declines of wader populations at the Tagus estuary, Portugal: a response to global or local factors? Bird Conserv. Int. doi: So959270910000626.

CMDSSS (China Meteorological Data Sharing Service System) (2010) Data set of monthly land surface climate value for China's international exchange station http://cdc.cma.gov.cn/shuju/index3.jsp? dsid=SURF_CLI_CHN_MUL_MON_CES\&pageid $=3$ (in Chinese) (accessed on 27 December 2010)

Crosby, M. J. and Chan, S. (2006) Threatened waterbird species in eastern and southern Asia and actions needed for their conservation. Pp. $332-338$ in G. C. Boere, C. A. Galbraith and D. A. Stroud, eds. Waterbirds around the world. Edinburgh, UK: The Stationery Office.

Dalby, R. (1957) Problems of land reclamation. Salt marsh in the Wash. Agric. Rev. 2: $31-37$.

Davidson, N. C., Lafoley, D. d'A., Doody, J. P., Way, L. S., Gordon, J., Key, R., Drake, C. M., Pienkowski, M. W., Mitchell, R. and Duff, K. L. (1991) Nature Conservation and estuaries in Britain. Peterborough, UK: Nature Conservancy Council.

Evans, P. R., Knights, D. M. and Pienkowski, M. W. (1979) Short-term effects of reclamations of part of Seal Sands, Teesmouth, on wintering waders and ducks. Oecologia 41: $183-206$. 
Glue, D. E. (1971) Saltmarsh reclamation stages and their associated bird-life. Bird Study 18: 187-198.

Gosbell, K. and Clemens, R. (2006) Population monitoring in Australia: some insights after 25 years and future directions. Stilt 50: $162-175$.

Goss-Custard, J. D. (1980) Competition for food and interference among waders. Ardea 68: 31-52.

Goss-Custard, J. D., Burton, N. H. K., Clark, N. A., Ferns, P. N., McGrorty, S., Reading, C. J., Rehfisch, M. M., Stillman, R. A., Townshend, I., West, A. D. and Worrall, D. H. (2006) Test of a behaviour-based individual-based model: response of shorebird mortality to habitat loss. Ecol. Appl. 16: 2215-2222.

HPDLR (Hebei Province Department Land \& Resources) (2007) Investigation and evaluation of marine resources in Hebei province: Synthesis report. Beijing, China: China Ocean Press.

IUCN (2010) IUCN Red List of Threatened Species. Version 2010.4. http:// www.iucnredlist.org(accessed on 16 December 2010).

Kim, T. I., Choi, B. H. and Lee, S. W. (2006) Hydrodynamics and sedimentation induced by large-scale coastal developments in the Keum River Estuary, Korea. Estuar. Coast. Shelf Sci. 68: 515-528.

Kraan, C., van Gils, J. A., Spaans, B., Dekinga, A., Bijleveld, A. I., van Roomen, M., Kleefstra, R. and Piersma, T. (2009) Landscapescale experiment demonstrates that Wadden Sea intertidal flats are used to capacity by molluscivore migrant shorebirds. J. Anim. Ecol. 78, 1259-1268.

Li, X. T., Qian, F. W., Liu, G. S., Zhang, Q. L. and Wang, J. D. (1996) The diversity of the waders (Charadiiformes) and the effects of oil contamination on it during the migration season in the coast of Bohai Bay. Chi. Biodiv. 4: 14-17. (In Chinese).

Liu, Y., Holt, P., Lei, J. Y., Zhang, Y. and Zhang, Z. W. (2006) Distribution, numbers and age structure of Relict Gull (Larus relictus) in Bohai Bay, China. Waterbirds 29: $375-380$.

Liu, Y., Holt, P. and Zhang, Z. W. (2007) Wintering records of Saunders's Gull in
Bohai Bay, China. J. Yamashina Inst. Ornithol. 38: 100-103.

Minton, C., Wahl, J., Jessop, R., Hassell, C., Collins, P. and Gibbs, H. (2006) Migration routes of waders which spend the nonbreeding season in Australia. Stilt 50: 135-157.

Moores, N. (2006) South Korea's shorebirds: a review of abundance, distribution, threats and conservation status. Stilt 50: 62-72.

Moores, N., Rogers, D. I., Kim, R. H., Hassell, C. J., Gosbell, K., Kim, S. A. and Park, M. N. (2008) The 2006-2008 Saemangeum Shorebird Monitoring Program Report. Busan, Korea: Birds Korea.

Nie, H. T. and Tao, J. H. (2008) Impact of coastal exploitation on the eco-environment of Bohai Bay. The Ocean Engineering 26: 44-50. (In Chinese).

Piersma, T. (2007) Using the power of comparison to explain habitat use and migration strategies of shorebirds worldwide. J. Ornithol. 148 (Suppl.): $\mathrm{S}_{45}-\mathrm{S}_{59}$.

Piersma, T. (2009) Threats to intertidal softsediment ecosystems. Pp. 57-69 in S. Reinhard and H. Folmer, eds. Water policy in the Netherlands. Integrated management in a densely populated delta. Washington, DC: Resources for the Future.

Rogers, K. G. and Gosbell, K. (2006a) Demographic models for Red-necked Stint and Curlew Sandpiper in Victoria. Stilt 50: 205-214.

Rogers, D. I., Moores, N. and Battley, P. F. (2006b) Northwards migration of shorebirds through Saemangeum, the Geum Estuary and Gomso Bay, South Korea in 2006. Stilt 50: 73-89.

Rogers, D. I., Yang, H. Y., Hassell, C. J., Boyle, A. N., Rogers, K. G., Chen, B., Zhang, Z. W. and Piersma, T. (2010) Red Knots (Calidris canutus piersmai and C. c. rogersi) depend on a small threatened staging area in Bohai Bay, China. Emu 110: 307-215.

Sato, S. (2006) Drastic change of bivalves and gastropods caused by the huge reclamation projects in Japan and Korea. Plankton and Benthos Res. 1: 123-137.

SOAPRC (State Oceanic Administration People's Republic of China) (2009) Communique on Marine Environment Quality of 
Bohai Sea 2008. http://www.coi.gov.cn/ hygb/dfhjzl/2008/bh/ (in Chinese) (accessed on 18 March 2010).

Southey, I. (2009) Numbers of waders in New Zealand 1994-2003. Wellington, New Zealand: New Zealand Department of Conservation. (DOC Research \& Development Series 308).

Suchaneck, T. H. (1994) Temperate coastal marine communities: biodiversity and threats. Am. Zool. 34: 100-114.

Syroechkovskiy, E. E. (2004) The Spoonbilled Sandpiper on the edge: a review of breeding distribution, population estimates and plans for conservation research in Russia. Pp. 169-174 in P. Straw, ed. Status and conservation of shorebirds in the East Asian-Australasian Flyway. Sydney, Australia: Wetlands International. (Wetlands International Global Series 18, International Wader Studies 17).

van de Kam, J., Ens, B., Piersma, T. and Zwarts, L. (2004) Shorebirds. An illustrated behavioural ecology. Utrecht, The Netherlands: KNNV Publishers.

van de Kam, J., Battley, P. F., McCaffery, B. J., Rogers, D. I., Hong, J. S., Moores, N., Ki, J.
Y., Lewis, J. and Piersma, T. (2008) Invisible connections. Why migrating shorebirds need the Yellow Sea. Wageningen, The Netherlands: Wetlands International.

Wan, J., Li, Z. C. and Lei, K. (2009) Dynamic analysis of the landscape spatial pattern in the coastal zone of the Bohai Bay, 19542000. Research of Env. Sci. 22: 77-82. (In Chinese)

Wetlands International (2006) Waterbird population estimate. Fourth edition. Wageningen, The Netherlands: Wetlands International.

Yang, H. Y. and Zhang, Z. W. (2006) Shorebirds wintering in Northern Bohai Bay. Stilt 49: 3-6.

Yang, H. Y., Chen, B. and Zhang, Z. W. (2008) Seasonal changes in numbers and species composition of migratory shorebirds in northern Bohai Bay, China. Wader Study Group Bull. 115: 133-139.

Zöckler, C., Syroechkovskiy, E. E. and Atkinson, P. W. (2010) Rapid and continued population decline in the Spoon-billed Sandpiper Eurynorhynchus pygmeus indicates imminent extinction unless conservation action is taken. Bird Conserv. Int. 20: 95-111.

HONG-YAN YANG

Key Laboratory for Biodiversity Science and Ecological Engineering, Beijing Normal University, Beijing 100875, China and Animal Ecology Group, Centre for Ecological and Evolutionary Studies, University of Groningen, P.O. Box 14, 9750 AA Haren, The Netherlands.

\section{BING CHEN}

Room 2511, Building 1, 2 Nan-Fang-Zhuang, Fengtai District, Beijing 100079, China.

\section{MARK BARTER}

School of Life Sciences, University of Science and Technology of China, Hefei, Anhui 230027, China.

\section{THEUNIS PIERSMA}

Animal Ecology Group, Centre for Ecological and Evolutionary Studies, University of Groningen, P.O. Box 11103, 9700 CC Groningen, The Netherlands and Department of Marine Ecology, Royal Netherlands Institute for Sea Research (NIOZ), P.O. Box 59, 1790 AB Den Burg, Texel, The Netherlands. 
CHUN-FA ZHOU

Key Laboratory for Biodiversity Science and Ecological Engineering, Beijing Normal University, Beijing 100875, China.

\section{FENG-SHAN LI}

International Crane Foundation, Baraboo, Wisconsin 53913, USA.

ZHENG-WANG ZHANG*

Key Laboratory for Biodiversity Science and Ecological Engineering, Beijing Normal University, Beijing 100875, China.

*Author for correspondence; e-mail: zzw@bnu.edu.cn

Received 17 July 2010; revision accepted 22 February 2011; Published online 18 May 2011 